\title{
KINEMATIC ANALYSIS OF "LOU YUN" VAULTS PERFORMED BY TOP LEVEL MALE GYMNASTS: RELATIONSHIP BETWEEN KINEMATIC VARIABLES AND JUDGES' SCORE
}

\author{
Roman Farana*, Jaroslav Uchytil, David Zahradník, Daniel Jandačka
}

Pedagogical Faculty, University of Ostrava, Ostrava, Czech Republic

Submitted in September, 2012

BACKGROUND: In gymnastics judging, evaluation of routines in their execution is based on form and technique displayed during the performance. A vaulting performance takes a short time and is affected by the quantity of biomechanical variables. The significant relationships between the vault score and specific aspects of the gymnast's vault should motivate coaches to monitor these variables as a part of training or routine testing.

OBJECTIVE: The purpose of the study was to determine the biomechanical variables that are related to a successful performance of Lou Yun vaults performed by top level male gymnasts during the World Cup competition.

METHODS: Ten top-level male gymnasts participated in this study. For the 3D kinematic analysis, two digital camcorders with a frame rate of $50 \mathrm{~Hz}$ were used. The data was digitized by Simi Motion software. The Hay and Reid method (1988) was used to identify the biomechanical variables that determine the linear motions of the Lou Yun vaults. A correlation analysis was used to establish the relationship between the biomechanical variables and the judges' scores. The level of statistical significance was determined at the value of $p<.05$.

RESULTS: Six out of 24 examined variables showed significant correlations with the scores. A significant correlation was found in the maximum height of the body centre of mass in the second flight phase $(r=.68)$, in the height of centre of mass at mat touchdown $(r=.75)$, in the relative height from table take-off to mat touchdown $(r=-.85)$, in the duration of the table contact phase $(r=-.71)$, in the duration of the second flight phase $(r=.62)$ and in the vertical velocity of body centre of mass at table take-off $(r=.70)$.

CONCLUSIONS: The results of the study suggest that a successful execution of Lou Yun vaults and the achievement of a higher score required: to minimize duration of table support phase; to maximize the vertical velocity in the table take-off phase; to maximize the amplitude of the second flight phase, which is determined by the duration of the second flight phase, by the maximum height of the body centre of mass in the second flight phase, and by the distance from the vaulting table during landing; and to maximize the height of the body centre of mass in the mat contact phase.

Keywords: Sports biomechanics, gymnastics, vault, technique, correlation analysis, performance.

\section{INTRODUCTION}

In gymnastics judging, evaluation of routines in their execution is based on form and techniques displayed during the performance (Takei, 1992). Artistic gymnastics is evaluated live by a panel of accredited judges using governing rules and performance-based criteria known as the Code of Points (Federation International de Gymnastique, 2009) to guide their observations (Bradshaw, Hume, \& Aisbett, 2012). To earn a high score, gymnasts must perform difficult routines with high accuracy and proper technique. Biomechanics is

\footnotetext{
* Address for correspondence: Roman Farana, Human Motion Diagnostic Centre, Pedagogical Faculty, University of Ostrava, Varenská 40a, 70200 Ostrava, Czech Republic. E-mail: roman.farana@osu.cz
}

well suited to examine, describe, develop and improve technique. Although many variables influence success in the sport, including psychological and physiological factors, biomechanical considerations as reflected in correct or incorrect technique are crucial (Prassas, Kwon, \& Sands, 2006).

Vaulting is the only gymnastic apparatus involving a single movement and, for this reason, vaulting is the most researched and best understood apparatus (Prassas et al., 2006). A vaulting performance takes a short time and is affected by the quantity of biomechanical variables (Farana \& Vaverka, 2012). Irrespective of the type of vault, successful performance requires the optimization of each aspect of the action; the run-up (or approach), pre-take-off hurdle, take-off, pre-flight, table contact, post-flight, and landing (Bradshaw, Hume, Calton, \& Aisbett, 2010). The handspring vault and 
their variations are examples of the continuous rotation vaults, in which the rotation of the body about the gymnast's transverse (or somersault) axis is in the same forward direction throughout (Takei, 1998; Takei, Blucker, Nohara, \& Yamashita, 2000). The Lou Yun vault (handspring and stretched somersault forward with one and one-half turns) is one of the most advanced variations of the handspring category performed in international competition.

Past research has attempted to quantify the relationship between each or multiple aspects of the vault and overall performance (i.e. judges' score); however, research has generally been completed prior to 2001 based on the old vaulting horse (Bradshaw et al., 2010). Those studies discuss the issue of biomechanical factors in the individual vault phases and their effect on the achieved score using deterministic models (Hay \& Reid, 1988). A deterministic model is a paradigm that determines the relationship between a movement outcome measure and the biomechanical factors that produce such a measure (Chow \& Knudson, 2011). The aim of the theoretical models in artistic gymnastics is to indicate the relationship between the resulting score and variables that affect the final score (Farana \& Vaverka, 2012; Krug et al., 1998; Naundorf et al., 2008; Penitente et al., 2009; Prassas, 2002; Takei, 1990, 1992, 1998, 2007; Takei et al., 2000; Van der Eb et al., 2012) or to optimize the course of the movement in the vault (Gervais, 1994). For instance, Takei (1998) found significant correlations $(p<.005)$ in horizontal velocity at board contact and board take-off, duration of pre-flight, vertical velocity at horse take-off, vertical height of post-flight and horizontal distance at landing. Krug et al. (1998) reported a moderate correlation $(r=.68, p<.01)$ between average run-up horizontal velocity and judges' score at the 1997 World Gymnastics Championships. Takei (2007) stated that peak height of centre of mass (COM) during post-flight phase was the best single predictor of the judges' score and accounted for $50 \%$ of variation in the judges' score. While comprehensive biomechanical data of vaulting using the new table (post 2000 Olympic competition) is not yet available (Bradshaw et al., 2010), two studies (Farana \& Vaverka, 2012; Van der Eb et al., 2012) provided an illustration of the relationship between biomechanical variables and judges' score using new vaulting table. Van der Eb et al. (2012) founded significant correlation $(p<.01)$ between velocity at takeoff and final judges' scores were $r=.60(p=.00)$ for men and $r=.52(p=.00)$ for women. For handspring and front somersaults group vaults in female gymnastics, Farana and Vaverka (2012) reported significant correlation $(p<.05)$ in the vertical height of the body center of mass during the take-off from the vaulting table $(r=.86)$, in the maximum height of the body center of mass in the second flight phase $(r=.83)$, in the change of the horizontal velocity during the phase of the takeoff from the vaulting table $(r=-.69)$, in the horizontal component of the velocity during the spring from the vaulting table $(r=.75)$ and in the duration of the second flight phase $(r=.69)$. The significant relationships between the vaulting score and specific aspects of the gymnast's vault should motivate coaches to monitor these variables as a part of training or routine testing. Evaluating changes in these predictive variables could highlight the gymnast's training progress between competitions (Bradshaw et al., 2010).

The purpose of the study was to determine the biomechanical variables that are related to a successful performance of the difficult handspring vaults performed by top level male gymnasts during the World Cup competition.

\section{METHODS}

\section{Participants}

Ten top-level male gymnasts $(N=10)$ who participated in the 2010 and 2011 World Cup competitions in the Czech Republic were involved in this study. All gymnasts were members of the national teams of the relevant countries. The age, height and mass of gymnasts were $21.40 \pm 1.88$ years, $167.80 \pm 4.71 \mathrm{~cm}$ and $64.60 \pm 4.50 \mathrm{~kg}$. All gymnasts performed the handspring vault (handspring and stretched somersault forward with one and one-half turns - Lou Yun) graded 6.2 points (FIG, 2009). The final score for vaults were $14.70 \pm 0.40$ points.

\section{Data collection}

For the 3D kinematic analysis, two digital camcorders (Panasonic NV-MX500EG, Japan) with a frame rate of $50 \mathrm{~Hz}$ were used. The shutter speed was set to $1 / 500 \mathrm{~s}$. The angle between the optical axes of the cameras was near to $90^{\circ}$ (Bartlett, 2007). Calibration of the space was defined by calibration poles which created virtual cube (Figure 1).

\section{Data analysis}

The data was digitized by the Simi Motion software (Simi Reality Motion Systems GmbH, Unterschleissheim, Germany). In each frame, the gymnast's head centre and centre of his hand segment, wrist joint, elbow joint, shoulder joint, hip joint, knee joint, ankle joint and foot segment on both sides of his body were digitized. A 14 segment model of the human body was created based on 17 body points. For the location of the centre of mass (COM), the Gubitz model (Gubitz, 1978) was used. For each vault, approximately 75 fields were digitized. These included every frame from five frames prior to the board touchdown to five 
after the mat touchdown. The 3D DLT method was used for calculating 3D coordinates of the digitized body parts (Abdel-Aziz \& Karara, 1971). The raw data were smoothed using a low-pass filter with the cut-off frequency of $8 \mathrm{~Hz}$ (Bartlett, 2007). The reconstruction accuracy was 0.013 meters within the 7 meters field of view. A sample vault trial was digitized twice to evaluate digitizer reliability (Irwin \& Kerwin, 2009; Kerwin \& Irwin, 2010). Reliability based on repeat digitization of a sample sequence was $<1 \%$ for temporal and spatial parameters and $<4.5 \%$ for velocity parameters. The data were manually digitized by an experienced researcher (Janura, Cabell, Svoboda, Elfmark, \& Janurová, 2011; Janura, Cabell, Svoboda, Elfmark, \& Zahálka, 2011).

\section{Measured biomechanical variables}

A theoretical model of biomechanical variables was used, according to the Hay and Reid method (1988) and study by Takei et al. (2000), to identify the biomechanical variables that determine the linear motions of gymnasts performing handsprings and front somersault vaults (Figure 2).
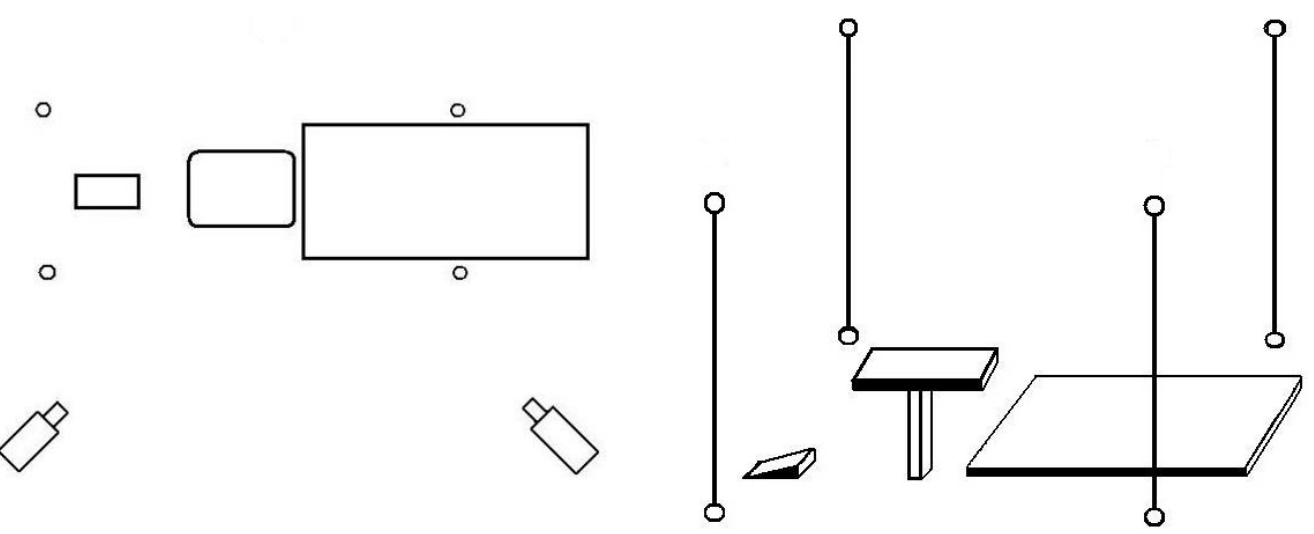

Figure 1. Positions of cameras and vaulting apparatus

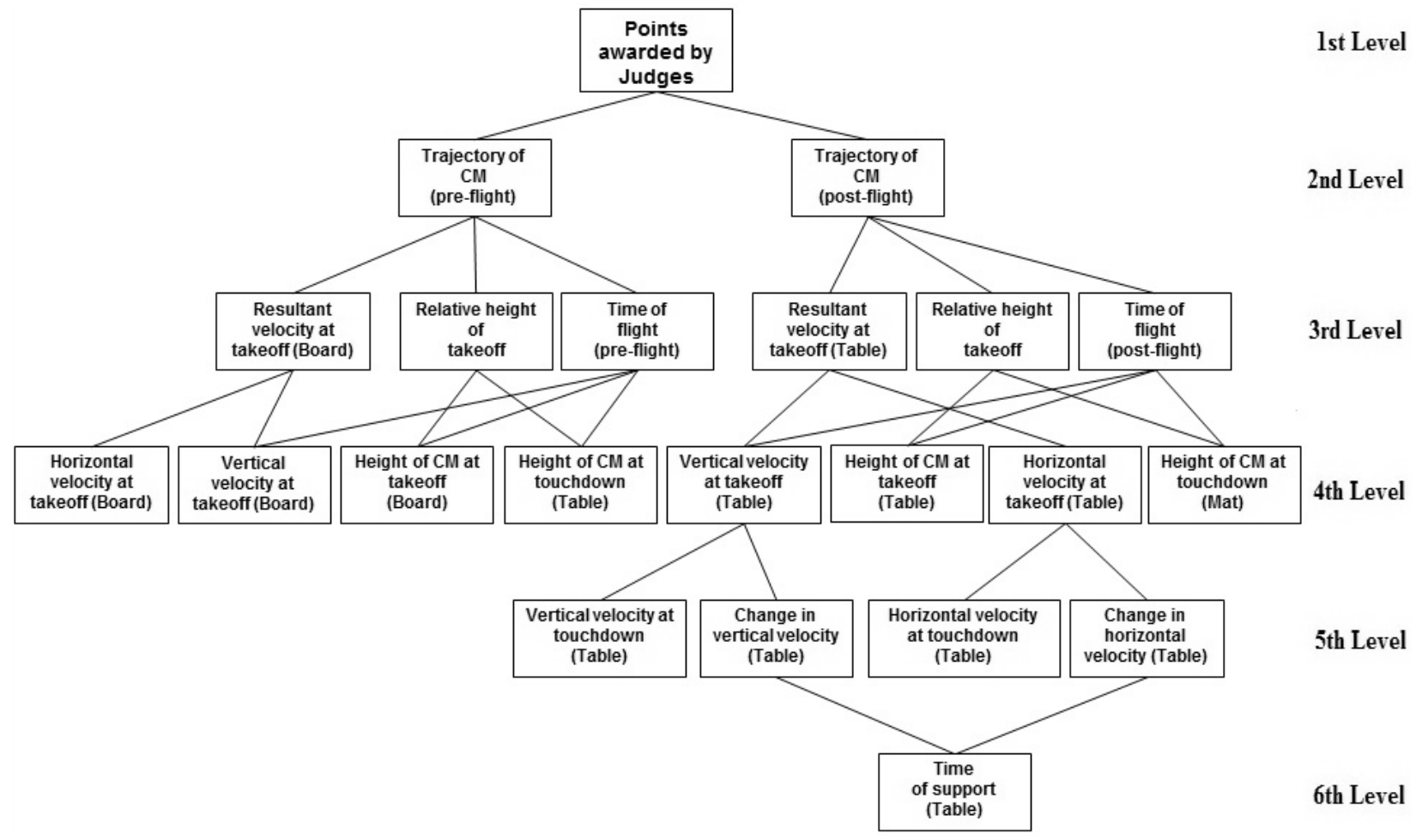

Figure 2. Model showing factors that determine the linear motions of the "Lou Yun" vault related to the judges' score 
According to the Hay and Reid method (1988), the model used in our study consisted of two factors (the trajectory of COM in the first flight and the trajectory of $\mathrm{COM}$ in the second flight) which are identified at the second level and linked to the points awarded by judges at the first level. The trajectory of the COM in the pre-flight is determined by the resultant velocity at the take-off from the board, the relative height of the take-off and the time of the first flight ( $3^{\text {rd }}$ level). The resultant velocity at the take-off from the board is the vector sum of the horizontal and vertical velocities at the take-off ( $4^{\text {th }}$ level). The relative height of the take-off is determined by the height of the COM at the board take-off and the height of the COM at the table touchdown $\left(4^{\text {th }}\right.$ level $)$. The time of the first flight is determined by the height of the $\mathrm{COM}$ and the vertical velocity at the take-off from the board and the height of the COM at the touchdown on the table ( $4^{\text {th }}$ level). As shown in Figure 2, the biomechanical variables which govern the trajectory of the COM in the second flight phase are similar to those identified on the third and fourth levels of the model for the first flight. More specifically, the vertical velocity at the take-off from the table shown at the fourth level is the sum of the vertical velocity at the touchdown on the table and the change in the vertical velocity that occurs while on the table ( $5^{\text {th }}$ level). The horizontal velocity at the take-off from the table shown at the fourth level is the sum of the horizontal velocity at the touchdown on the table and the change in the horizontal velocity that occurs while on the table $\left(5^{\text {th }}\right.$ level). The changes in the vertical and horizontal velocities are determined by the duration of the table support $\left(6^{\text {th }}\right.$ level $)$.

\section{Statistical analysis}

The mean and standard deviations $(M \pm S D)$ were calculated for each variable. The box-plot was used for outliers identification. To express the statistical relation between the dependent variables and independent variables, the Pearson correlation coefficient $(r)$ was used. The level of statistical significance was determined to be $p<.05$. A coefficient of determination $\left(r^{2}\right)$ was calculated for all independent variables: the coefficient is used to express the relation of the explained variability to the total variability of dependent variable (Takei, 2007). IBM SPSS Statistic 19 was used for statistical analysis.

\section{RESULTS}

The descriptive statistics $(M \pm S D)$, correlation coefficients $(r)$ and the coefficient of determination $\left(r^{2}\right)$ for the temporal, spatial and velocity parameters of the ten handspring vaults executed by the male gymnasts that achieved the highest score are outlined in Table 1 and 2.

As for the temporal and spatial parameters, a total of fifteen variables were examined, while a significant relationship to the score was found in five variables (Table 1). As for the temporal parameters, a significant correlation was found in the time of the table support phase $(r=-.71 ; p=.01)$ and time of the second flight phase $(r=.62 ; p=.03)$. As for the spatial variables significant relationships to the score were found in the maximum height of the body COM in the second flight phase $(r=.68 ; p=.015)$, in the vertical height of the body COM at the mat touchdown $(r=.75 ; p=.006)$ and in the relative height of body COM at table take-off to mat touchdown $(r=-.85 ; p=.001)$.

As for the velocity parameters, a total of nine variables were examined, while a significant relationship was determined in one of them (Table 2). A significant relationship was found in the vertical velocity of the body COM at the table take-off $(r=.70 ; p=.013)$.

\section{DISCUSSION}

The aim of the study was to determine the biomechanical variables that govern success in the performance of the Lou Yun vault (handspring and stretched somersault forward with one and one-half turns). In this section we discussed the results of our study relative to the judge's score and to the previous literature results and conclusions. Based on our results, we also discussed the practical significance for gymnastics training. Takei (2007) states that from the practical point of view, each independent variable that can explain more than $10 \%$ of the total variability of the dependent variable (judges' score) is important for further training.

\section{Temporal and spatial parameters and judges' score}

As for temporal variables, negative significant correlation $(r=-.71 ; p<.05)$ was founded in time of table contact phase. This variable can explain approximately $50 \%$ of the total variability of the score (Table 1 ). The negative correlation means that the shorter the duration of the take-off phase, the better the execution of the vault is and the better the possibility of a higher score is. This has also been confirmed by Bradshaw and Sparrow (2001) who characterize an explosive take-off by the short duration of the contact that is in a moderate correlation with the duration of the second flight phase $(r=-.41 ; p<.05)$ and the resulting score $(r=-.59 ; p<.05)$. A short contact time on the take-off board and/or vaulting table is likely to transform the gymnast's approach velocity into a longer second flight time (Bradshaw, 2004) or distance provided that the gymnast performs a sufficient impulse through good body mechanics (Bradshaw et al., 2010). Significant 
Table 1

Relationship between temporal and spatial variables and the judges' score in critical phases of the $\operatorname{vault}(N=10)$

\begin{tabular}{|c|c|c|c|c|c|}
\hline Variable & $M \pm S D$ & Minimum & Maximum & $r$ & $r^{2}$ \\
\hline Judges' score & $14.70 \pm 0.40$ & 14.00 & 15.60 & - & - \\
\hline \multicolumn{6}{|l|}{ Time (s) } \\
\hline On board & $0.09 \pm 0.02$ & 0.08 & 0.12 & -.31 & .10 \\
\hline First flight & $0.15 \pm 0.02$ & 0.12 & 0.16 & .51 & .26 \\
\hline On table & $0.16 \pm 0.03$ & 0.12 & 0.20 & $-.71^{*}$ & .50 \\
\hline Second flight & $0.96 \pm 0.09$ & 0.88 & 1.12 & $.62^{*}$ & .38 \\
\hline \multicolumn{6}{|l|}{ Horizontal displacement of COM (m) } \\
\hline First flight & $0.98 \pm 0.23$ & 0.70 & 1.50 & .03 & .01 \\
\hline Second flight & $4.31 \pm 0.44$ & 3.57 & 5.05 & .54 & .29 \\
\hline Official distance of second flight & $2.86 \pm 0.21$ & 2.35 & 3.15 & .42 & .18 \\
\hline \multicolumn{6}{|l|}{ Height of COM at critical instants (m) } \\
\hline Board take-off & $1.24 \pm 0.10$ & 1.12 & 1.39 & -.16 & .03 \\
\hline Table touchdown & $1.79 \pm 0.11$ & 1.64 & 1.99 & .26 & .07 \\
\hline Table take-off & $2.28 \pm 0.10$ & 2.19 & 2.50 & .07 & .01 \\
\hline Peak of second flight & $2.85 \pm 0.23$ & 2.56 & 3.28 & $.68^{*}$ & .46 \\
\hline Mat touchdown & $0.89 \pm 0.12$ & 0.75 & 1.15 & $.75^{* *}$ & .56 \\
\hline \multicolumn{6}{|l|}{ Relative height of take-off (m) } \\
\hline Board take-off to table touchdown & $0.55 \pm 0.09$ & 0.40 & 0.65 & .53 & .28 \\
\hline Table touchdown to table take off & $0.49 \pm 0.06$ & 0.42 & 0.60 & -.39 & .15 \\
\hline Table take-off to mat touchdown & $1.39 \pm 0.11$ & 1.16 & 1.53 & $-.85^{* *}$ & .72 \\
\hline
\end{tabular}

Note. $\quad r=$ Pearson coefficient of correlation, $r^{2}=$ coefficient of determination.

Statistically significant correlations are in boldface; ${ }^{*} p<.05,{ }^{* *} p<.01$.

Table 2

Relationship between velocity variables and the judges' score in critical phases of the vault $(N=10)$

\begin{tabular}{lccccc}
\hline \multicolumn{1}{c}{ Variable } & $M \pm S D$ & Minimum & Maximum & $r$ & $r^{2}$ \\
\hline Judges' score & $14.70 \pm 0.40$ & 14.00 & 15.60 & - & - \\
Resultant velocity (m/s) & & & & & \\
$\quad$ Board take-off & $6.20 \pm 0.36$ & 5.27 & 6.47 & .02 & .01 \\
$\quad$ Table take-off & $4.50 \pm 0.48$ & 3.66 & 5.43 & .50 & .25 \\
Horizontal velocity (m/s) & & & & & \\
Board take-off & $5.00 \pm 0.33$ & 4.32 & 5.45 & .05 & .01 \\
Change on table & $-1.28 \pm 0.40$ & -1.94 & -0.55 & -.47 & .22 \\
Table take-off & $3.26 \pm 0.30$ & 2.80 & 3.81 & -.13 & .02 \\
Vertical velocity (m/s) & & & & & \\
Board take-off & $3.71 \pm 0.27$ & 3.38 & 3.98 & -.06 & .01 \\
Table touchdown & $3.36 \pm 0.39$ & 2.98 & 4.17 & .54 & .29 \\
Change on table & $-0.59 \pm 0.38$ & -1.32 & -0.08 & .50 & .25 \\
Table take-off & $2.77 \pm 0.62$ & 2.00 & 3.77 & $.70^{*}$ & .49 \\
\hline
\end{tabular}

Note. $\quad r=$ Pearson coefficient of correlation, $r^{2}=$ coefficient of determination.

Statistically significant correlations are in boldface; ${ }^{*} p<.05$. 
correlation $(r=.62 ; p<.05)$ was founded in time of post-flight phase and it can explain approximately $38 \%$ of the total variability of the score (Table 1). An increase in the second flight time provides gymnasts with the ability to complete more complex acrobatic movements in the air, thus increasing the degree of difficulty and the potential for a high score (Bradshaw et al., 2010). This has also been reported by Takei et al. (2000) and Takei (1998) who found in these variables significant correlation with the judges' score. As Bradshaw et al. (2010) state, temporal variables are an important and reliable training indicator of vaults from various groups at various performance levels of competitive gymnasts. We assume that the temporal parameters are observable variables from the aspect of the score and thus it is possible to partially predict a successful score.

As for the spatial parameters, significant relationships were found in the maximum height of the body COM in the second flight phase $(r=.68 ; p<.05)$ and the vertical height of the body COM at the mat touchdown $(r=.75 ; p<.01)$. These two variables are very important for further training from the aspect of statistical significance as the achieved maximum height of the body COM can explain about $46 \%$ and the height of the body COM at the mat touchdown can explain up to $56 \%$ of the total variability of the score (Table 1 ). The Code of Points states that somersault vaults must display a distinct opening phase in preparation for landing (FIG, 2009). To observe this rule, the time of the second flight phase and the height of the body COM at the mat touchdown are decisive. The previous studies by Takei (2007) and Takei et al. (2007) confirm the significance of those variables from the aspect of the score. Takei et al. (2007) found significant differences $(p<.05)$ between the "Roche" vaults that obtained higher and lower scores. The vaults with a higher score reached a higher height of the body COM during the second flight phase as well as at the mat touchdown. As Prassas (2002) states, the height of the body COM at the mat touchdown determines the level of squat and incomplete rotation during landing. Significant negative correlation $(r=-.85 ; p<.01)$ was found in the relative height of body COM at table take-off to mat touchdown (Table 1). Also, a significant negative correlation $(r=-.93 ; p<.01)$ was found between the maximal height of the body COM in post-flight and the duration of the contact with the vaulting table. Therefore, coaches should focus on minimizing the duration of the contact with the vaulting table for maximizing the height of the body COM in the post-flight phase, for instance by suitable exercises from the take-off upper extremities training blocks (Cuk \& Karacsony, 2004; Farana \& Vaverka, 2012). No significant relationship was found between the horizontal distance of the body
COM, official distance during landing and the judge's score. Previous studies by Takei et al. (2000) and Takei (2007) found significant relationships for those variables. However, in our study the horizontal distance of the body COM and the official distance during landing may be considered practically significant and it may explain about $29 \%$, respectively $18 \%$ of the score variability.

\section{Velocity parameters and judges' score}

As for the velocity parameters, a significant correlation was found in the vertical velocity of body COM at the table take-off $(r=.70 ; p<.05)$. This variable can explain about $49 \%$ of the total score variability (Table 2). Vertical velocity is considered to be the key variable in achieving a sufficient height of the vault, which is also confirmed by the results of previous studies (Cuk \& Karacsony, 2004; Prassas, 2002; Takei, 1998; Takei et al., 2003; Takei \& Kim, 1990). Irwin and Kerwin (2009) found that the introduction of a new vaulting table significantly increased vertical velocity in handspring vaults in the phase of the table take-off. We can thus presume that when a gymnast takes off the vaulting table with a high vertical velocity, he will achieve a sufficient height during the second flight phase and have thus a higher potential of obtaining a higher score. According to the Code of Points, the gymnast must demonstrate a distinct increase in the height of his body after the take-off from the table and the gymnast must show a considerable increase of his COM above its height at the moment of the hand take-off (FIG, 2009). For compliance with these rules, a high vertical velocity during the take-off from the vaulting table followed by a sufficient height of the second flight phase is necessary. Vertical velocity can be thus considered a variable that can partially predict the score. The practical significance found in the change of the horizontal velocity of body COM in the vaulting table take-off phase indicates that the least possible loss of the gained velocity affects the following successful execution of the vault and can explain approximately $22 \%$ of the total score variability (Table 2 ). George (2010) states that a performer must trade-off a small portion of horizontal velocity to reap tremendous dividends in rotation. We also found practical significance in the change of vertical velocity of body COM during the take-off from the vaulting table, which can explain about $25 \%$ of the total score variability (Table 2). This means that gymnasts are able to produce a high vertical velocity important for the height of the second flight phase and controlled landing in the short time interval of the vaulting table take-off phase. This is supported by Takei et al. (2000) who state that a short time of the table support, a high vertical impulse and increase in vertical velocity during the take-off are necessary for 
a higher score. George (2010) stated that to sticking the landing, the vertical component is always easier to control than the horizontal.

\section{Study limitation}

Although our study has brought some interesting findings in the field of kinematics of the examined group of vaults, to understand this issue better, it is necessary to work with a larger sample size of top-level gymnasts under the conditions of a real competition and to broaden the research to vaults from other vault groups (e.g. Yurchenko group). However, small sample sizes are a common feature when undertaking research at elite competition (Kerwin \& Irwin, 2010; Manning et al., 2010). Random errors arising from field data collection were minimised through careful calibration and digitising procedures and examined through error analysis.

\section{CONCLUSIONS}

Based on the deterministic model, we determined variables that have a significant effect on scoring concerning vaults from the handspring group. In the Lou Yun vaults, in six out of 24 variables arising from the deterministic model showed a significant relationship to the score. The results of the study suggest that a successful execution of Lou Yun vaults and the achievement of a higher score required:

- Decreasing the duration of the table support phase.

- Increasing the vertical velocity in the table take-off phase.

- Increasing the amplitude of the second flight phase, which is determined by the duration of the second flight phase, by the maximum height of the body $\mathrm{COM}$ in the second flight phase, and by the distance from the vaulting table during landing.

- Increasing the height of the body COM in the mat contact phase.

\section{ACKNOWLEDGMENTS}

This research was supported by University of Ostrava SGS grant 2011.

\section{REFERENCES}

Adbel-Aziz, Y. I., \& Karara, H. M. (1971). Direct linear transformation for comparator coordinates in to object space coordinates in close range photogrammetry. In Proceedings of the ASP Symposium in Close-range Photogrammetry (pp. 1-18). Urbana, IL: American Society of Photogrammetry.
Bartlett, R. (2007). Introduction to sports biomechanics: Analysing human movement patterns (2nd ed.). Abingdon, UK: Routledge, Taylor and Francis group.

Bradshaw, E. (2004). Target-directed running in gymnastics: A preliminary exploration of vaulting. Sports Biomechanics, 3(1), 125-144.

Bradshaw, E., Hume, P., \& Aisbett, B. (2012). Performance score variation between days at Australian national and Olympic women's artistic gymnastics competition. Journal of Sports Sciences, 30(2), 191-199.

Bradshaw, E., Hume, P., Calton, M., \& Aisbett, B. (2010). Reliability and variability of day-to-day vault training measures in artistic gymnastics. Sport Biomechanics, 9(2), 79-97.

Bradshaw, E., \& Sparrow, W. A. (2001). The approach, vaulting performance, and judge's score in women's artistic gymnastics. In J. R. Blackwell \& R. H. Sanders (Eds.), XIX International Symposium of Biomechanics in Sports (pp. 311-314). San Francisco, CA: University of San Francisco.

Chow, J. W., \& Knudson, D. (2011). Use of deterministic models in sports and exercise biomechanics research. Sports Biomechanics, 10(3), 234-248.

Cuk, I., \& Karacsony, I. (2004). Vault: Methods, ideas, curiosities, history. Ljubljana: ŠTD Sangvinčki.

Farana, R., \& Vaverka, F. (2012). Kvalitativní př́istup $\mathrm{k}$ analýze pohybu vybraných přeskoků ve sportovní gymnastice: př́ípadová studie. Česká kinantropologie, 16(2), 141-152.

Farana, R., \& Vaverka, F. (2012). The effect of biomechanical variables on the assessment of vaulting in top-level artistic female gymnasts in World Cup competitions. Acta Universitatis Palackianae Olomoucensis. Gymnica, 42(2), 49-57.

Federation International de Gymnastique. (2009). Code of Points - Men's artistic gymnastics. Lucerne, Switzerland: Rueber.

Gervais, P. (1994). A prediction of an optimal performance of the handspring $1 \frac{1}{2}$ front salto longhorse vault. Journal of Biomechanics, 27(1), 67-75.

George, G. S. (2010). Championship gymnastics: Biomechanical techniques for shaping winners. Carlsbad, CA: Wellness Press.

Gubitz, H. (1978). Zur analytischen Bestimmung der Lage des Koerperschwerpunktes. In International Symposium (pp. 171-180). Berlin.

Hay, G. J., \& Reid, G. J. (1988). Anatomy, mechanics and human motion (2nd ed.). Upper Saddle River, NJ: Prentice Hall.

Irwin, G., \& Kerwin, D. (2009). The influence of the vaulting table on the handspring front somersault. Sports Biomechanics, 8(2), 114-128. 
Janura, M., Cabell, L., Svoboda, Z., Elfmark, M., \& Janurová, E. (2011). Analysis of the beginning of the early flight phase of the ski jump in athletes with different performance levels. Acta Universitatis Palackianae Olomoucensis. Gymnica, 41(3), 7-13.

Janura, M., Cabell, L., Svoboda, Z., Elfmark, M., \& Zahálka, F. (2011). Kinematic analysis of the takeoff and start of the early flight phase on a large hill (HS-134 m) during the 2009 Nordic World Ski Championships. Journal of Human Kinetics, 27(1), 5-16.

Kerwin, D. G., \& Irwin, G. (2010). Musculoskeletal work preceding the outward and inward Tkachev on uneven bars in artistic gymnastics. Sports Biomechanics, 9(1), 16-28.

Krug, J., Knoll, K., Köthe, T., \& Zocher, D. H. (1998). Running approach velocity and energy transformation in difficult vaults in gymnastics. In H. J. Riehle \& M. M. Vieten (Eds.), XVI International Symposium of Biomechanics in Sports (pp. 160-163). Konstanz: Universitatsverlag Konstanz.

Manning, M. L., Irwin, G., Gittoes, M. J. R, \& Kerwin, D. G. (2011). Influence of longswing technique on the kinematics and key release parameters of the straddle Tkachev on uneven bars. Sports Biomechanics, 10(3), 161-173

Naundorf, F., Brehmer, S., Knoll, K., Bronst, A., \& Wagner, R. (2008). Development of velocity for vault runs in artistic gymnastics for last decade. In Y. H. Kwon, J. Shim, J. K. Shim, \& I. S. Shin (Eds.), XXVI International Symposium of Biomechanics in Sports (pp. 481-484). Seoul: ISBS.

Penitente, G., Merni, F., \& Fantozzi, S. (2009). Onboard anf pre-flight mechanical model of Yurchenko one twist on vault: Implications for performance. In A. J. Harrison, R. Anderson, \& I. Kenny (Eds.), XXVII International Symposium of Biomechanics in Sports (pp. 636-639). Limerick: ISBS.

Prassas, S. (2002). Vaulting mechanics. In K. E. Gianikellis (Ed.), XX International Symposium of Biomechanics in Sports (pp. 1-4). Cáceres: ISBS.

Prassas, S., Kwon, Y. H., \& Sands, W. A. (2006). Biomechanical research in artistic gymnastics: A review. Sports Biomechanics, 5(2), 261-291.

Takei, Y. (1990). Technique used by elite women gymnasts performing a handspring vault at the 1987 Pan American Games. International Journal of Sport Biomechanics, 6(1), 29-55.

Takei, Y. (1992). Blocking and post flight technique of male gymnasts performing the compulsory vault at the 1988 Olympics. International Journal of Applied Biomechanics, 8(2), 87-110.

Takei, Y. (1998). Three-dimensional analysis of handspring with full turn vault: Deterministic model, coaches' beliefs, and judges' scores. Journal of Applied Biomechanics, 14(2), 190-210.

Takei, Y. (2007). The Roche vault performed by elite gymnasts: Somersaulting technique, deterministic model, and judges' scores. Journal of Applied Biomechanics, 23(1), 1-11.

Takei, Y., Blucker, E., Nohara, H., \& Yamashita, N. (2000). The Hecht vault performed at the 1995 World Gymnastics Championships: Deterministic model and judges' scores. Journal of Sports Sciences, 18(11), 849-863.

Takei, Y., Dunn, H., \& Blucker, E. (2003). Techniques used in high-scoring and low-scoring 'Roche' vaults performed by elite male gymnasts. Sports Biomechanics, 2(2), 141-162.

Takei, Y., \& Kim, J. (1991). Techniques used in performing the handspring and salto forvard tucked vault at the 1988 Olympic games. International Journal of Applied Biomechanics, 6(2), 111-138.

Van der Eb, J., Filius, M., Ruogoor, G., Van Niel, C., de Water, J., Coolen, B., \& de Koning, H. (2012). Optimal velocity profiles for vault. In E. Bradshaw, A. Burnett, \& P. Hume (Eds.), XXX International Symposium of Biomechanics in Sports (pp. 71-75). Melbourne: ISBS.

\section{KINEMATICKÁ ANALÝZA PŘEMETOVÝCH \\ PŘESKOKŮ V PROVEDENÍ VRCHOLOVÝCH SPORTOVNÍCH GYMNASTU゚: VZTAH MEZI KINEMATICKÝMI PROMĚNNÝMI A BODOVÝM HODNOCENÍM}

(Souhrn anglického textu)

VÝCHODISKA: Ve sportovní gymnastice jsou výkony a jejich provedení hodnoceny na základě techniky a estetiky během cvičení. Sportovní výkon v přeskoku trvá krátký čas a je ovlivněn velkým množstvím biomechanických proměnných. Statisticky významné vztahy mezi bodovým hodnocením a biomechanickými veličinami v průběhu skoku mohou být pro trenéry podnětem ke sledování těchto proměnných jako části tréninkového procesu a přispět tak ke zlepšení sportovního výkonu $\mathrm{v}$ přeskoku.

CÍL: Cílem studie je určit, které biomechanické faktory se podílejí na úspěšném hodnocení složitých přemetových skoků v provedení vrcholových sportovních gymnastů během závodu světového poháru.

METODY: Výzkumu se účastnilo deset vrcholových sportovních gymnastů. Pro 3D analýzu byly použity dva digitální kamkordéry se snímkovací normou $50 \mathrm{~Hz}$. Data byla digitalizována pomocí softwaru Simi Motion. Metoda podle Hay a Reid (1988) byla použita pro identifikaci biomechanických proměnných, které ovlivňují průběh přemetových skoků. Pro posouzení 
závislosti mezi biomechanickými proměnnými a bodovým hodnocením byla použita korelační analýza. Hladina statistické významnosti byla nastavena na hladinu $p<0,05$.

VÝSLEDKY: Z 24 vyšetřovaných proměnných byly u pěti zjištěny signifikantní korelace s bodovým hodnocením. Signifikantní korelace byla zjištěna u maximální výšky těžiště těla ve druhé letové fázi $(r=0,68)$, výšky těžiště těla při doskoku $(r=0,75)$, relativní výšky od odrazu ze stolu po kontakt doskokové žíněnky $(r=-0,85)$, doby trvání fáze kontaktu přeskokového stolu $(r=-0,71)$, doby trvání druhé letové fáze $(r=0,62)$ a vertikální rychlosti těžiště při odrazu ze stolu $(r=0,70)$.
ZÁVĚRY: Výsledky naší studie ukazují, že pro úspěšné hodnocení přeskoku Lou Yun je nutné: minimalizovat dobu trvání kontaktu s přeskokovým stolem; maximalizovat vertikální rychlost těžiště těla při odrazu $\mathrm{z}$ přeskokového stolu; maximalizovat rozsah druhé letové fáze, který je definován dobou trvání druhé letové fáze, maximální výškou těžiště těla ve druhé letové fázi a horizontální vzdáleností od přeskokového stolu při doskoku; maximalizovat výšku těžiště těla při kontaktu doskokové žíněnky.

Klíčová slova: sportovní biomechanika, gymnastika, preskok, technika, korelační analýza, provedení. 